\title{
Influence of Electromagnetic Effects on the Parameters of the Formation of Secondary Ecosystems
}

\author{
Maria Vasilyeva*, Stanislav Kovshov, Anna Zelentsova \\ Saint Petersburg Mining University, 21-st line of Vasilyevskiy Island 2, St. Petersburg, Russia, 199106
}

Received: 28 September 2020

Accepted: 31 October 2020

\begin{abstract}
The article presents the results of studies that allow us to assess the environmental impact of various types of electromagnetic fields on the effectiveness of subsequent remediation measures and the inclusion of areas that have been exposed to electromagnetic effects in residential areas, as well as the use of agricultural land. The growth dynamics of biotest objects of vegetation planted in technogenic soil that has undergone preliminary treatment with electromagnetic fields of various nature was evaluated. An assessment was also made of the effect of magnetization on the structure of the soil and its filtration ability, including the change in the state of soil layers caused by the action of electromagnetic fields on inherent moisture. As a result of the research, data were obtained that make it possible to assess the degree of influence of electromagnetic fields of various kinds on the effectiveness of subsequent reclamation measures and the use of the inclusion of zones exposed to electromagnetic effects in the composition of residential areas, as well as for agricultural land. Thus, plants planted in technogenic soil, previously subjected to electromagnetic influence, demonstrate a pronounced inhibition of ontogenesis, this effect is enhanced if the soil was previously in a moist state. It was found that the introduction of fertilizers into the soil, previously subjected to electromagnetic action, has a beneficial effect on plant growth, but their effectiveness is significantly reduced.
\end{abstract}

Keywords: secondary ecosystem, technogenesis, reclamation, electromagnetic field, magnetotropism

\section{Introduction}

The vast majority of the needs for minerals are satisfied by mankind through the development of mineral deposits. In turn, the extraction and processing of mineral raw materials leads to large-scale, negative

*e-mail: saturn.sun@mail.ru multi-faceted environmental impacts and, as a result, to significant social and economic losses.

Technogenic formations have recently attracted serious attention, determined by: firstly, the possibility of using them as mineral resources; secondly, the environmental hazard created by the harmful effects on the environment. As a product of human endeavor, man-made deposits are concentrated in areas of cities and other settlements, creating an increased danger to life activity in them [1-3]. 
The negative environmental consequences of mining are expressed in the seizure and violation of thousands of hectares of land, pollution of ground and surface waters, soil, atmosphere, destruction of vegetation, changes in the existing hydrobalance in vast territories. The created situation can be successfully resolved by combining operations on the processing of technogenic formations and technical reclamation of excavated quarries and mine collapse zones.

Since in most cases the volume of space mined is greater than or equal to the volume of dumps and tailings, when storing secondary waste into the waste space, there is no need to allocate new land for storage. This ensures technical reclamation and the return to economic circulation of almost all lands disrupted by mining operations, eliminates technogenic formations, which are constantly operating foci of pollution of the atmosphere, groundwater and surface water, ensures the constancy of the mineral and chemical composition of secondary waste for their subsequent deeper processing. The latter advantage is very significant, since technogenic formations deposited on the earth's surface undergo a continuous change due to the oxidation and subsequent leaching of sulfides.

At present, certain practical experience has already been accumulated in the use of the developed spaces as landfills for the disposal of non-toxic and lowtoxic mining waste [4-8]. At the same time, such a rock stored in a mined-out space, tailings or dumps can become maternal in the formation of secondary ecosystems, largely determining the local geochemical cycle of matter and energy.

However, as practice has shown, in addition to the positive aspects with this approach to solving the problem, there is a risk of groundwater pollution due to their mixing with the liquid phase of the pulp or precipitation, which are contaminated by filtration through the thickness of industrial waste.

To prevent this threat, it is necessary to eliminate or minimize the hydraulic connection between the waste stored in the mine workings and underground water bodies and the main way to achieve this is to store waste with a low liquid content. This leads to difficulties in delivering them to the underground space, especially to far located workings.

The modern market offers various designs of pumping equipment capable of pumping mixtures with a high solids content, but the efficient transportation of highly thickened hydraulic mixtures is problematic due to the rapid wear of the pump elements and, as a consequence, premature failure of the equipment [9].

A fundamentally new approach to the transportation of pasty and viscous substances is the use of equipment capable of being less susceptible to abrasive wear, the working area of which is outside the existing nonlinear dependence between the efficiency of traditional equipment and the concentration of the solid phase, as well as the kinematic viscosity coefficient of the substance. At St. Petersburg Mining University, research is being conducted on the use of a magnetic peristaltic mono-pump for laying mined-out space with highly condensed hydraulic mixtures [10]. This equipment, in which the motion of a substance is caused by a quasistationary magnetic field, provides an intense physical effect on the components of the hydraulic mixture, organizing their movement along predetermined trajectories with a low shear stress.

The main tasks that need to be solved for the successful implementation of the above-mentioned idea are: justification of the technology for the delivery of waste, including to far located workings; substantiation of the composition of the filling array from the products of the utilization of technogenic waste from the extraction and processing of mineral resources. However, it also requires careful consideration and detailed analysis of the effect of this method of transporting the filling mixture on the state of the environmental situation on the land allotment. This aspect has not yet received wide consideration in the scientific and technical literature, therefore, conducting experimental and theoretical studies will help to identify rational areas of application of magnetization from the position of its influence on various parameters of emerging ecosystems.

Despite the large number of studies related to magnetotropism, work that would allow us to assess the effect of electromagnetic effects on industrial soils with respect to the potential danger and effectiveness of further land restoration and their use as residential areas, as well as for further agricultural work, has not been paid enough attention in Russian and foreign literature.

Most of the works are devoted to studying the effect of magnetization of seeds of various plants before planting [11-16], studying the effect of magnetic fields on the process of their growth and development [17-20], and also the effect of magnetic fields on soil microflora [21-23]. This effect was studied by various groups of researchers in natural and laboratory conditions. And always test plants showed a reaction to the direction of the magnetic field [24-27].

\section{Material and Methods}

In studying the environmental effects of magnetic fields on the soil, the biotest method was used. The seeds of lawn grass, turnip onions, mid-ripe leaf lettuce and early-ripening cold-resistant radish were used as planting material. Planting of seeds was carried out in a technogenic sod-podzolic low-humus loamy soil. At one of the stages of the experiments, fertilizers based on the products of birds vital activity were used: biochar and vermicompost.

The experiments were carried out in laboratory conditions. The plants were grown under artificial lighting and an electric light source was used, since it stimulates plant growth due to the emission of electro- 
magnetic waves, favorable for photosynthesis [28, 29]. The average ambient temperature was $17^{\circ} \mathrm{C}$, the average humidity was $65 \%$, And the average illumination was about 800-1000 lux.

An alternating current winding generator made in the form of an "expanded stator" was used as a running electromagnetic field (RMF) source: current strength - $4.7 \mathrm{~A}$; voltage - $125 \mathrm{~V}$, frequency $40 \mathrm{~Hz}$. RMF can be defined as a quasistationary magnetic field that varies sinusoidally in time at each point in space, and all points with the same amplitude and phase of oscillation in time move linearly at a constant speed in space.

The direct electromagnetic field (DeMF) was created by an electromagnet, manufactured by Bairum Electric $\mathrm{CO}$, parameters: current strength - $1 \mathrm{~A}$, voltage $-12 \mathrm{~V}$.

To assess the effect of magnetic influence on technogenic soils, a set of physiological parameters of plants was chosen, which allows the rapid assessment method to be implemented [30]. These parameters were: shoot density, stem height, color, number of shoots, state of the root system.

Watering and measurement of physiological parameters of plants was carried out for 7 weeks (from February 11 to March 27, 2020).

\section{Results and Discussion}

\section{Investigation of the Effect of Electromagnetic Fields on Dry Soil}

Soil magnetization was carried out portionwise. Unmoistened soil was packaged in portions of 250 grams and distributed in the active zone of the electromagnetic field source with a layer of $1.5-2 \mathrm{~cm}$. The exposure time to the soil was 5 minutes.

Plastic cassettes from interconnected cells with a size of $5.5 \times 5.7 \times 6$ with a drainage hole were used as plots for planting samples. About $90-100 \mathrm{ml}$ of magnetized technogenic sod-podzolic soil were taken into each of them. Next, seeds were planted in equal quantities and with a uniform coating of the sown area and irrigated with about $30 \mathrm{ml}$ of clean water at room temperature for moisture impregnation of the entire cell profile.

The results of the experiments were subjected to statistical processing: calculated the average value, the error of the average and the reliability of the difference between the options. The results are presented on Fig 1.

As can be seen from Fig. 1, the effect of preliminary magnetization of technogenic soil in two different ways has a significant impact on the basic physiological parameters of biotest objects. The germination of grass during the processing of the soil with the RMF turned out to be almost 2 times lower than when exposed to DeMF.

When evaluating onion germination, the length of the stalks of green onions was estimated. This parameter turned out to be almost 2 times greater in the case of preliminary exposure to DeMF soil. At the same time, the root system of onions planted in soil exposed to RMF showed a superficial deepening in the soil, without significant germination in depth, the bulbs themselves were sluggish and largely lost their internal volume.

By analyzing the growth dynamics of biotest objects, one can trace the tendency that, regardless of the type of plant, the germination of the sample under the influence of RMF always occurred earlier. However, then the growth rate was significantly reduced compared with the sample planted in the soil subjected to DeMF treatment. This may be due to the residual magnetization affecting the soil when exposed to RMF, which manifests itself as a cumulative effect.

The Study of the Influence of the Electromagnetic Field when Exposed to Dry Soil and Subsequent Fertilizer Application.

The second stage of the study of the influence of the influence of the electromagnetic field on plant growth was the introduction of fertilizers into the premagnetized soil and the subsequent planting of biotest objects. In the experiment, we used vermicompost, a)

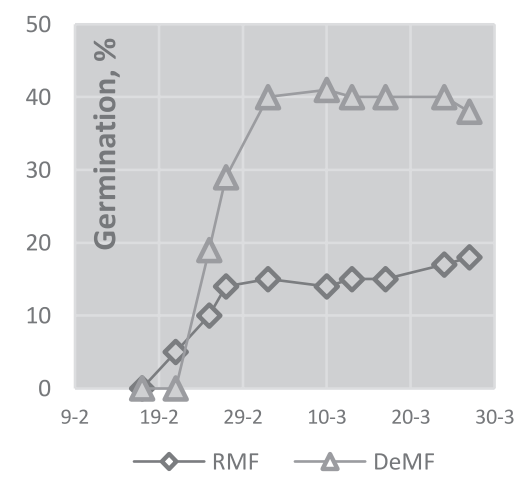

b)

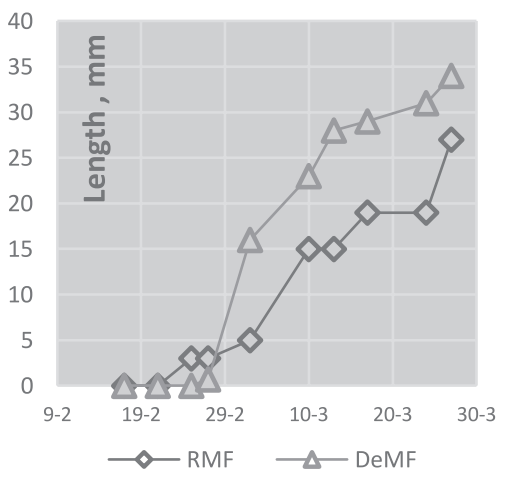

c)

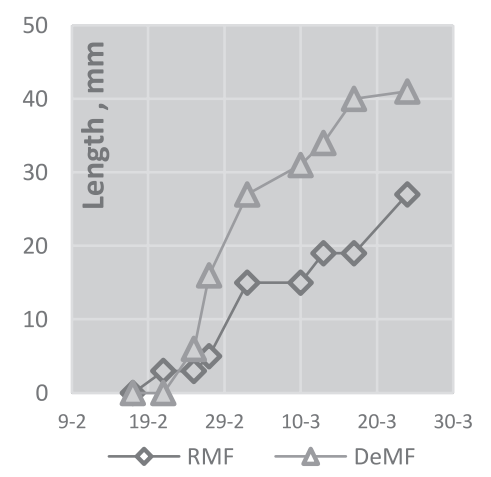

Fig. 1. Growth dynamics of biotest objects during preliminary processing of technogenic soil by magnetic fields: a) grass germination; b) the length of the stem of the grass; in - the length of green onions. 

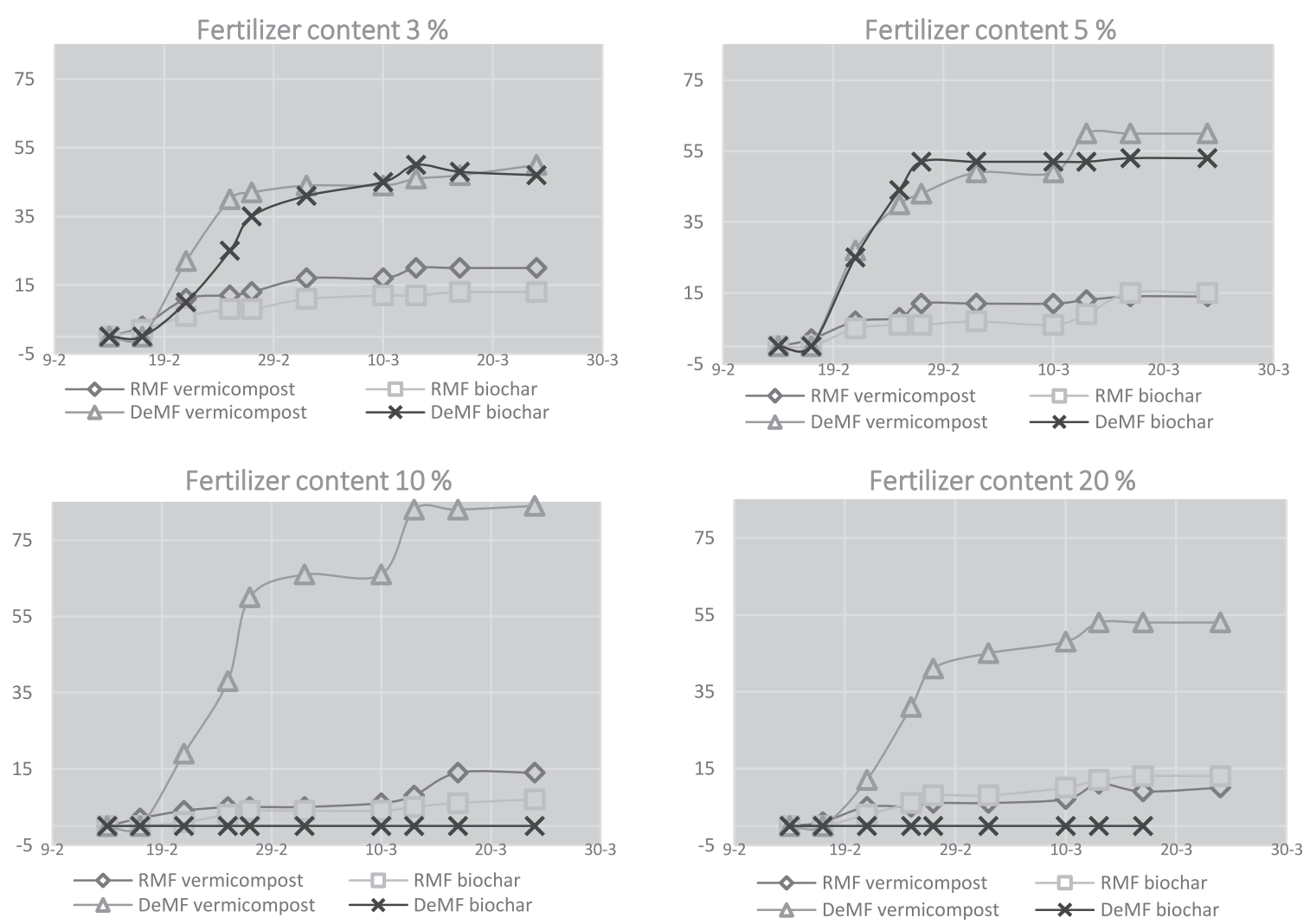

Fig. 2. Grass germination (\%) at various concentrations of organic fertilizers under conditions of treatment with various magnetic fields.
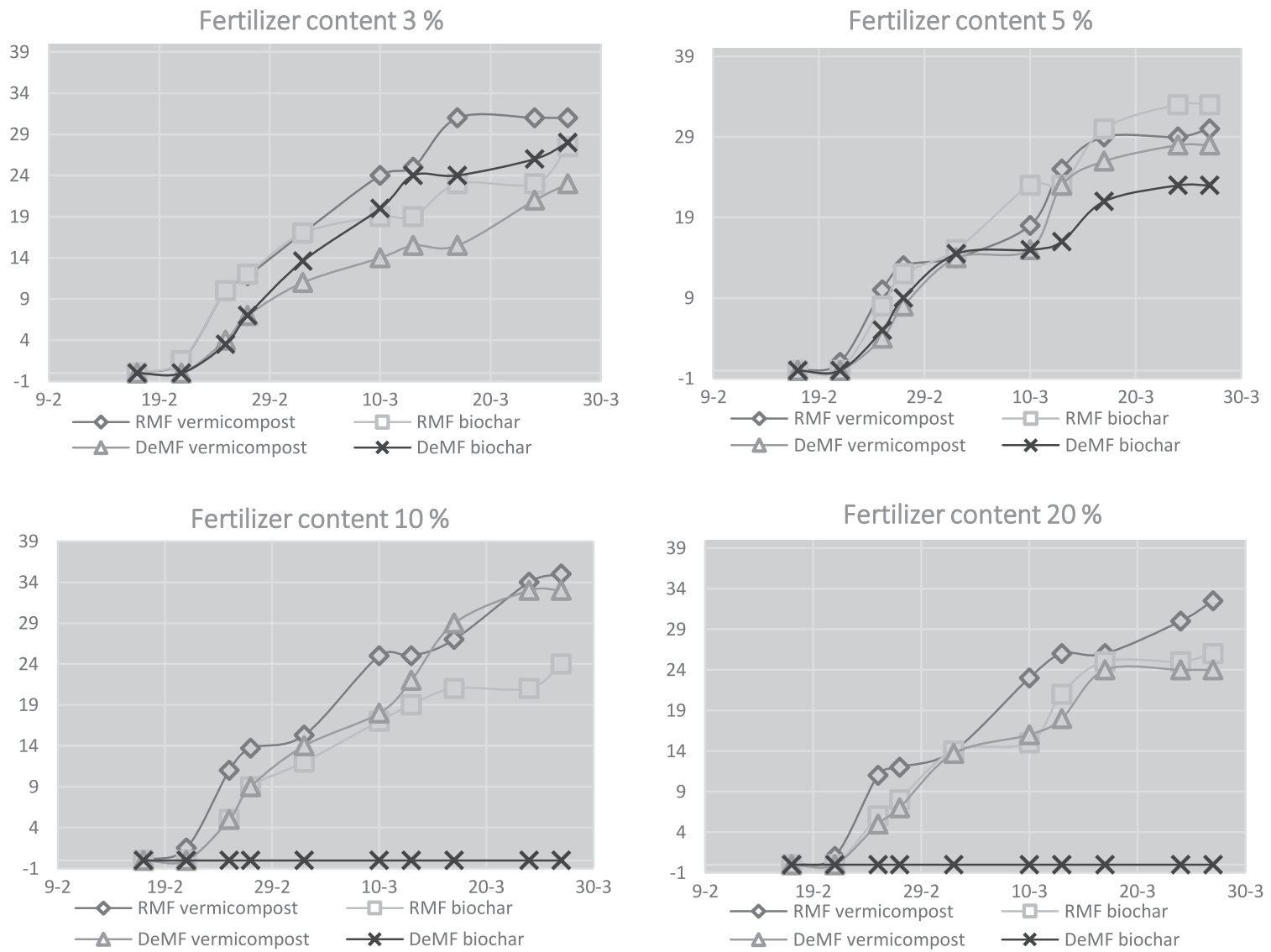

Fig. 3. Raising the height of grass stems at various concentrations of organic fertilizers under conditions of treatment with various magnetic fields, $\mathrm{mm}$. 
an organic fertilizer obtained from the processing of rotten chicken droppings using earthworm composts of the species Eisenia foetida, and biochar, a potassium phosphorus fertilizer obtained from incomplete twostage burning of chicken droppings.

Soil magnetization was carried out similarly to the first experiment.

Then, using a measuring cup for each cell, a volume of approximately 90-100 $\mathrm{ml}$ of magnetized technogenic sod-podzolic soil was selected, to which fertilizer was added in a certain proportion relative to the initial soil volume $(3 \%, 5 \%, 10 \%, 20 \%)$.

An analysis of grass growth showed that when fertilizers are applied in concentrations of 3 and $5 \%$, the dynamics of plant germination during soil cultivation with a DeMF is 3-4 times higher than that of objects planted in soil exposed to an RMF (Fig. 2). At the same time, with an increase in the concentration of fertilizers in the soil exposed to the DeMF, germination also increases, and with preliminary exposure of the soil to the RMF, the germination of biotest objects, on the contrary, worsens. This trend continues with a further increase in the content of fertilizers in the soil. It should be noted that when biochar is added in concentrations of more than 5\% to anthropogenic soil exposed to DeMF, grass seeds do not germinate. This is probably determined by a significant increase in the alkaline properties of the soil during polarization of the microstructural formations of the soil in this way with a relatively large specific volume of biochar (Fig. 2).

The dynamics of raising the height of grass stems when applying fertilizers to soil subjected to magnetic treatment is presented in Fig. 3.

An analysis of the height of the grass stems showed that when the soil was exposed to the RMF, the level of stem rise was $10-20 \%$ higher than this parameter for objects planted in the soil subjected to magnetization by the DeMF (Fig. 4).

The growth dynamics of the bulbous plant is shown in Fig 5. The height parameter of the feathers of green onions was estimated.

An analysis of the growth of biotest objects of turnip onion, planted in soil subjected to preliminary magnetization by an electromagnetic field of various nature, showed that with a low content of biohumus in soil treated with RMF, growth retardation of green onion stems is observed. With an increase in the concentration of fertilizer, the growth curves are aligned, which can be explained by the achievement of a certain soil saturation, at which the required amount of micronutrient fertilizers enters the plant, regardless of external factors.

Since the results of biotests showed that in the absence of fertilizers in the soil, the greatest inhibition of the studied objects is observed when RMF is exposed to them, the next stage of the experiments was carried out only with its use.

\section{Investigation of the Influence of Electromagnetic Fields on Wet Soil}

As test objects in this experiment, seeds of mid-ripe leaf lettuce and early-ripening cold-resistant radish were used to exclude the probability of a specific reaction of specific plant varieties to the effect of an electromagnetic field.

The soil was moistened in a ratio of 1 : 3.6 (0.7 1 of water per 2.51 of soil). A reservoir with moistened rock was installed in the active zone of the RMF field generator and was treated for 5 minutes. For a comparative assessment of the effect of the magnetization effect, seeds of the same plants were planted in equal quantities in soil moistened in a similar proportion and not subjected to magnetic treatment.

With an interval of 7 days, the dynamics of plant growth was evaluated.

In the first observation, test objects of leaf lettuce planted in the soil subjected to magnetic treatment sprouted by $15 \%$; radish test objects sprouted $90 \%$. Samples showed weak sprouting, low rise of sprouts, yellowness of leaves and reddening of stems. Test objects of leaf lettuce and radish, sprouting in untreated soil, sprouted $100 \%$. Samples exhibit a healthy uniform color.

Further observation of growth showed that the germination of leaf lettuce is low, the seeds did not germinate in full. Sprouts have a short stem length, expressed by its lethargy and yellowness. Radish seeds a)

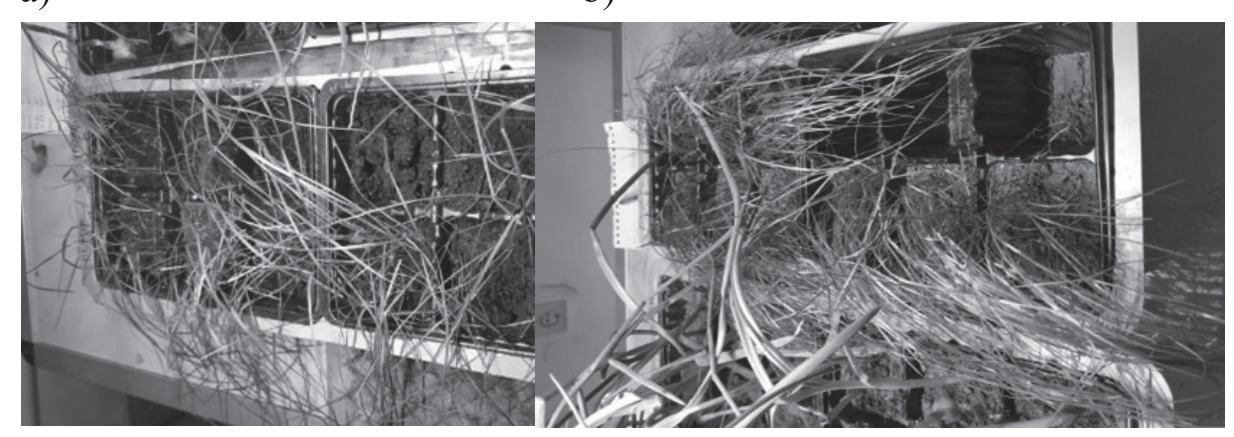

Fig. 4. The appearance of the plots of grass at the final stage of the experiment: a) when exposed to an RMF; b) when exposed to a DeMF. 

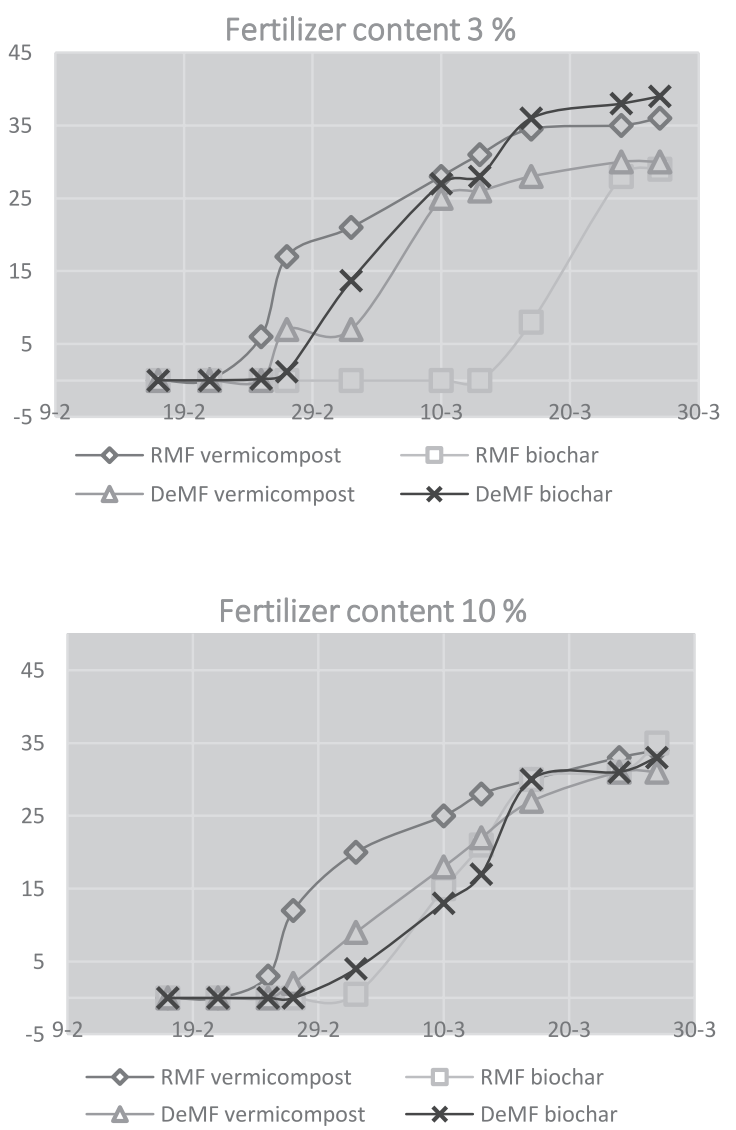

Fig. 5. The height of the stalks of green onions, $\mathrm{mm}$.

sprouted completely, but sprouts also show lethargy of stems and low growth.

The growth dynamics of test objects planted in soil that has not undergone magnetic treatment corresponds to the physiology of the corresponding plants. The difference in the height of lettuce sprouts was $41 \%$, the radish growth $17 \%$ in favor of samples grown in soil that was not subjected to magnetic treatment.

\section{Discussion}

All rocks to a greater or lesser extent have magnetic properties. the bulk of rock-forming minerals belongs to the group of paramagnets. Furthermore, in the ground almost always contains some ferromagnetic compounds [31, 32].

The magnetic properties of the rock are characterized by magnetic susceptibility, coercive force, and residual magnetization. These characteristics depend on the structure, the ratio of para-, dia-, ferromagnetic components, mineral and chemical composition of the soil. The magnetic properties of the rock must be taken into account because of its effect on the deposition of rocks, the formation of structure and texture, and the mechanical properties of suspensions and sediments [33-37].

Magnetization of rocks is important in the formation of various types of soils, especially finely dispersed
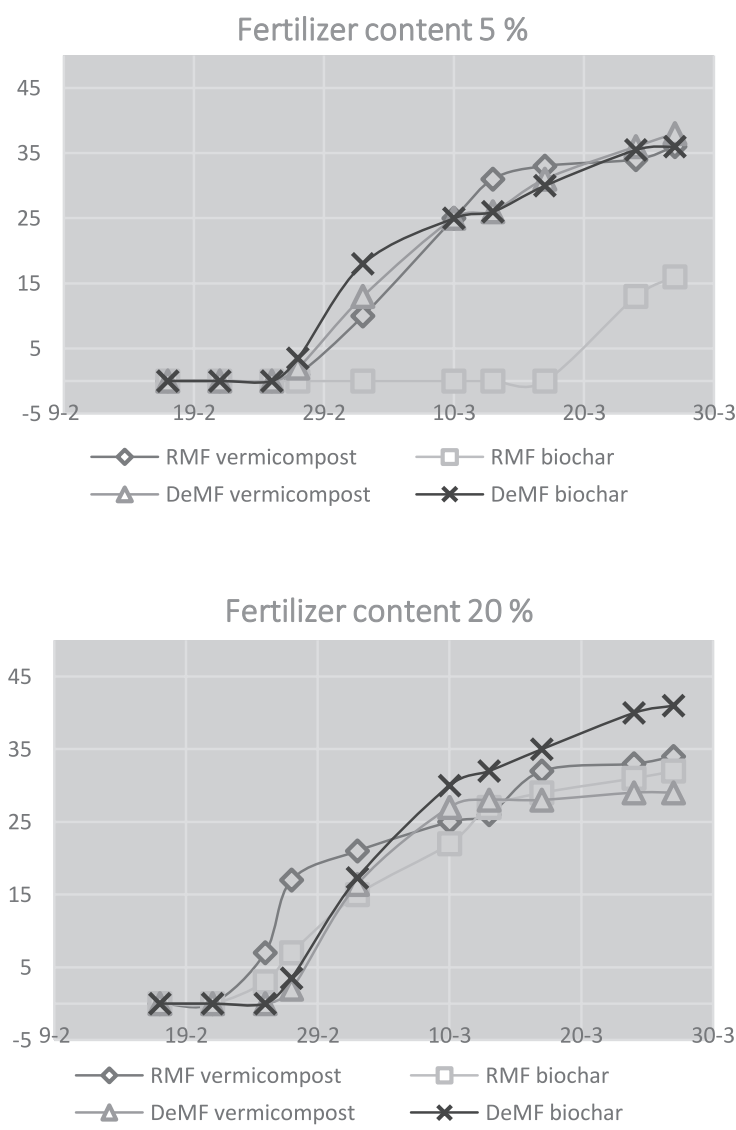

clay varieties [38]. Studies of the behavior of clay suspensions, pastes, and sediments in a magnetic field showed that the magnetic properties of minerals and a magnetic field significantly affect the deposition of clay rocks and the formation of their structural and textural features and, as a consequence, the mechanical and rheo-logical properties of both clay suspensions and formed precipitation [39-44].

During the processing of the soil by an electromagnetic field, it was noted that magnetization helps to improve the state of aggregation of soils in the upper layers, which contributed to an increase in the rate of filtration of water in it by $20-30 \%$ in the first hours after treatment. Also, magnetic soil treatment provides additional salt removal to the lower layers up to $20 \%$. Sodium sulfate, the most difficult to remove during salt leaching in industrial soils, was more leached out, which is also confirmed by studies of other groups of authors [45-48].

Another circumstance related to the influence of magnetic treatment on the formation parameters of secondary ecosystems is the fact that the bound water contained in the hydraulic mixtures freezes after magnetization of the moistened rock at temperatures from -5 to $-100^{\circ} \mathrm{C}$, depending on a number of additional factors. This is of great importance during mining waste disposal in regions with frozen conditions, affecting the ice content of the soil and 
the depth of seasonal thawing. According to the information contained in the works of some research groups, magnetic soil cultivation can be used to protect crops from frost [49-51], however, the results obtained on the basis of assessing the germination of biotest objects in previously moistened soil make us look at this fact in a comprehensive manner, namely: while changing the freezing temperature of the soil, a magnetic field, especially quasi-stationary, can significantly reduce the germination and slow down plant growth.

Observations of the growth of biotest objects made it possible to conclude that the samples planted in the soil subjected to magnetic treatment show slow growth, as well as a general depressed state. The color, size and tone of the plants indicates their weakness. It is also worth noting that test samples sprouted simultaneously with samples sown in soil not subjected to magnetic treatment, despite the relative weakness, subsequently showed steady growth. The same seeds that germinated later were more weakened. This may be due to the effect of the residual magnetization of the soil, as well as the moisture distributed in it, on the plant germ. The longer the seeds were under a similar effect, the weaker the plant became. This effect was also observed in assessing the state of the root system of test plants. In plants planted in untreated soil, the roots corresponded to the physiology of plants for each of the stages of development. In samples planted in magnetized soil, the root system was at a less pronounced stage of development, the average length and thickness of root processes significantly lagged behind the plant parameters for each of the development stages, and the general state was inhibited. This overwhelming effect also indicates the influence of electromagnetic fields on the number of soil microorganisms, which, if used properly, can be useful in agriculture as a way to prevent damage to plants or the spread of various diseases.

\section{Conclusions}

When developing mineral deposits, the natural environment within the mining allotment and the adjacent territory experiences a significant impact, essentially turning into a new (secondary) environment, the leading factor of transformation of which is "technogenesis".

At the same time, the functioning and development of the new ecological system within the naturaltechnogenic ecosystem complex is determined both by natural conditions and the nature and depth of the influence of production on the abiotic and biotic components of the environment. The studies conducted allowed us to assess the degree of influence of various types of electromagnetic fields on the effectiveness of subsequent remediation measures and the use of the inclusion of zones that were exposed to electromagnetic effects in residential areas, as well as for agricultural land, and specifically:

1. Plants growing in man-made soil, previously subjected to electromagnetic treatment, show a marked decrease in the rate of ontogenesis. In this case, a quasistationary electromagnetic field has the most noticeable effect on the growth of plants in previously moistened soil.

2. The introduction of fertilizers into the soil, previously subjected to electromagnetic influence, has a beneficial effect on the growth of plants, however, their effectiveness is significantly reduced. The most vulnerable substance, when used as a fertilizer to enhance plant growth, is biocoal.

3. Magnetization affects the filtration characteristics of the soil, significantly increasing them due to the formation of internal structures due to the presence of ferromagnetic components in technogenic soil. This feature contributes to a more rapid leaching of salts from the soil.

4. Electromagnetic effects on soils also affect inherent moisture, as a result of which freezing of these soils occurs at lower temperatures.

A study of the magnetization of anthropogenic soil showed that fields of various nature have a noticeable complex effect on ecosystem parameters. Moreover, this influence in its properties in some cases can have conflicting dual results, as a result of which, when choosing technologies for mining, reclamation and restoration work, it is necessary to be guided by the specific conditions of the formed natural-technological ecosystem complexes.

\section{Acknowledgements}

This work was financially supported by the Russian Science Foundation, grant No. 19-79-10151.

The authors are grateful to the leadership of the Center for Collective Use of the Saint-Petersburg Mining University, Scientific and Educational Center for the Collective Use of High-Tech Equipment, as well as the department of technical support of scientific research led by Ph.D. D.O. Nagornov for help in organizing experimental research.

\section{Conflict of Interest}

The authors declare no conflict of interest.

\section{References}

1. STEWART V.I., SCULLION J. Principles of managing manmade soils. Soil Use and Management, 5 (3), 109, 1989.

2. SANO S., KONGO H., UCHIYAMA T. Characteristics of man-made soils of greenhouse fields in urban areas, Osaka Prefecture, Japan. Soil Science and Plant Nutrition, 61, 123, 2015. 
3. VYROZHEMSKY V., VOLOSHYNA I. Stability of Slopes and Embankments of Coarse Man-made Soils. Procedia Engineering, 143, 750, 2016.

4. AZAROV S.V., USMANOVA T.V., MEZHIBOR A.M. Environmental problems of mining waste disposal sites in Russia. Reviews of Environmental Contamination and Toxicology, 247, 59, 2019.

5. KMIECIK E., STEFANIAK S., SZCZEPAŃSKA J., TWARDOWSKA I. Evaluation of temporal and spatial trends of groundwater quality alteration in the area of mining waste disposal site. Proceedings of SPIE - The International Society for Optical Engineering, 5586 (22), 126, 2004.

6. LIU J., TENG Y., JIANG Y., GONG E. A cost compensation model for construction and demolition waste disposal in South China. Environmental Science and Pollution Research, 26 (14), 13773, 2019.

7. DAGILIUTE R., JUOZAPAITIENE G. Socio-economic assessment in environmental impact assessment: Experience and challenges in Lithuania. Journal of Environmental Engineering and Landscape Management, 23 (3), 211, 2015.

8. EBEREMU A.O. Evaluation of bagasse ash treated lateritic soil as a potential barrier material in waste containment application. Acta Geotechnica, 8 (4), 407, 2013.

9. VASILYEVA M.A. An overview of development trends for the pumping equipment of mining and processing enterprises, Obogashchenie Rud, 1, 51, 2019.

10. VASILYEVA M.A. Magnetic peristaltic pumps for backfill. Eurasian Mining, 1, 34, 2019.

11. MUTHERT L.W.F., IZZO L.G., van ZANTEN M., ARONNE G. Root Tropisms: Investigations on Earth and in Space to Unravel Plant Growth Direction. Frontiers in Plant Science, 10, 1807, 2020

12. CASSAB G.I., EAPEN D., CAMPOS M.E. Root hydrotropism: An update. American Journal of Botany, $100(1), 14,2013$

13. VOLKOV A.G., VOLKOVA M.I., MARKIN V.S. Phytosensors and phytoactuators. ECS Transactions, 50 (12), 2012.

14. SHABRANGI A., SHEIDAI M., MAJ A., NABLUNI M., DORRANIAN D. Cytogenetic abnormalities caused by extremely low frequency electromagnetic fields in canola. Science Asia, 36 (4), 292, 2010.

15. YANO A., HIDAKA E., FUJIWARA K., IIMOTO M. Induction of primary root curvature in radish seedlings in a static magnetic field. Bioelectromagnetics, 22 (3), 194, 2001

16. THORNE M.C. Radioecology in Europe. Journal of Radiological Protection, 38 (1), 2018.

17. TEIXEIRA da SILVA J.A., DOBRÁNSZKI J. Magnetic fields: how is plant growth and development impacted, 253 (2), 231, 2016.

18. FERRADA P., RODRÍGUEZ S., SERRANO G., MIRANDA-OSTOJIC C., MAUREIRA A., ZAPATA M. An analytical-experimental approach to quantifying the effects of static magnetic fields for cell culture applications. Applied Sciences, 10 (2), 531, 2020.

19. MICHALAK I., LEWANDOWSKA S., NIEMCZYK K., DETYNA J., BUJAK H.b, ARIK P., BARTNICZAK A. Germination of soybean seeds exposed to the static alternating magnetic field and algal extract Engineering in Life Sciences, 19 (12), 986, 2019.

20. BUKHARI S.A., FARAH N., MUSTAFA G., MAHMOOD S., NAQVI S.A.R., Magneto-Priming Improved Nutraceutical Potential and Antimicrobial
Activity of Momordica charantia L. Without Affecting Nutritive Value. Applied Biochemistry and Biotechnology, 188 (3), 878, 2019.

21. VANEK YU., KREMER YU. Microstructural changes in soil mass under the influence of a magnetic field. Soil Science, 10, 144, 1976.

22. OLSHANSKAYA L.N., TITORENKO O.V., EREMEEVA Y.A. Influence of a Constant Magnetic Field and Ultraviolet Radiation on Growth of Higher Plants and Phytoremediation of Soil from Oil Products. Chemical and Petroleum Engineering, 51 (5-6), 361, 2015.

23. DENISOVA T.V., KAZEEV K.SH. The effect of alternating and constant magnetic fields on the biota and biological activity of ordinary chernozem. Radiation biology. Ra-dioecology, 47 (3), 345, 2007.

24. BINGI V.N. Magnetobiologia, eksperymenty i modele. MILTA: Moskwa, Rosja, 592, 2000.

25. SELIM A., ZAYED M., ZAYED M. Magnetic field treated water effects on germination, growth and physiochemical aspects of some economic plants. Acta Botanica Hungarica, 55 (1-2), 99, 2013

26. ROHINSON E.E., TCHAIKOVSKY JI.A. The effect of an inhomogeneous magnetic field on the biological activity of soil. Abstracts of the $2^{\text {nd }}$ Congress of the Society of Soil Scientists, St. Petersburg, 285, 1996.

27. SHLYAKHTIN G.V., CHUMAKOV M.I., ZAVYALOV E.V. The effect of electromagnetic radiation on the growth and development of plants and associated microorganisms associated with them. High technology, 1, 12, 2003.

28. SYAKIR N., SYARIFUDIN F., HIDAYAT S., FITRILAWATI R. Modification of Blue LED using Organic-Inorganic Hybrid Polymer Doped with Nile Red for Artificial Lighting of Photosynthesis. Journal of Physics: Conference Series. 877 (1), 012016, 2017.

29. KIM S.C., MASON A., IM W. Enhancement of the initial growth rate of agricultural plants by using static magnetic fields. 2016 (113), e53967, 2016.

30. KOVSHOV S.V., CHERKAY Z.N. Expert assessment of the state of industrial safety in the territorial units of the mineral resource complex of Russia. Notes of the Mining In-stitute. 219, 477, 2016.

31. RAMDHANI R., FITRIANI D., KIRANA K.H., WIJATMOKO B., SUTANTO O. Magnetic properties of soils from landslide potential area (Case study: Pasir Ipis Lembang, West Bandung). Journal of Physics: Conference Series, 739 (1), 012107, 2015.

32. FIALOVÁ H., MAIER G., PETROVSKÝ E., KAPIČKA A., BOYKO T., SCHOLGER R. Magnetic properties of soils from sites with different geological and environmental settings. Journal of Applied Geophysics. 59 (4), 273, 2006.

33. KANU M.O., MELUDU O.C., BASAVAIAH N., ONIKU A.S. Relationship between mineral magnetic properties and soil textural parameters. Acta Geophysica, 67 (2), 517, 2019.

34. HATFIELD R.G. Particle size-specific magnetic measurements as a tool for enhancing our understanding of the bulk magnetic properties of sediments. Minerals, 4 (4), 758, 2014.

35. BAKHTEEVA I., MEDVEDEVA I., BYZOV I., ZHAKOV S., YERMAKOV A., UIMIN M., SHCHEGOLEVA N. Magnetic field-enhanced sedimentation of nanopowder magnetite in water flow. Environmental Technology (United Kingdom), 36 (14), 1828, 2015.

36. MAHER B.A. Characterisation of soils by mineral magnetic measurements. Physics of the Earth and Planetary Interiors, 42 (1-2), 76, 1986. 
37. TILL J.L., JACKSON M.J., ROSENBAUM J.G., SOLHEID P. Magnetic properties in an ash flow tuff with continuous grain size variation: A natural reference for magnetic particle granulometry. Geochemistry, Geophysics, Geosystems, 12 (7), Q07Z26, 2011.

38. LI J., PENG X., XIE W., RONG X., ISLAM N., QIAO S., ZHU J. Effect of high magnetic field premagnetization on the flocculation sedimentation of high turbidity clay sewage. Meitan Xuebao/Journal of the China Coal Society, 44 (7), 2253, 2019.

39. ZIELIŃSKI M., RUSANOWSKA P., DĘBOWSKI M., Hajduk A. Influence of static magnetic field on sludge properties. Science of the Total Environment. 625 (1), 738, 2018.

40. WU X, YUE T., DAI L. Magnetic seeding sedimentation (MSS) of coal slimes. IOP Conference Series: Earth and Environmental Science, 52 (1), 012003, 2017.

41. FEDOTOV G.N., SHEIN E.V., PUTLYAEV V.I., ARKHANGEL'SKAYA T.A., ELISEEV A.V., MILANOVSKII E.Yu. Physicochemical bases of differences between the sedimentometric and laserdiffraction techniques of soil particle-size analysis. Eurasian Soil Science, 40 (3), 281, 2007.

42. HATFIELD R.G. Particle size-specific magnetic measurements as a tool for enhancing our understanding of the bulk magnetic properties of sediments. Minerals, 4 (4), 758, 2014.

43. OLDFIELD F., HAO Q., BLOEMENDAL J., GIBBSEGGAR Z., PATIL S., GUO Z. Links between bulk sediment particle size and magnetic grain-size: General observations and implications for Chinese loess studies. Sedimentology, 56 (7), 2091, 2009.

44. JORDANOVA D., JORDANOVA N. Diversity and peculiarities of soil formation in eolian landscapes -
Insights from the mineral magnetic records. Earth and Planetary Science Letters, 531, 115956, 2020.

45. MINNIKOVA T.V., DENISOVA T.V., KOLESNIKOV S.I., TRUSHKOV A.V. The effect of the combined effect of nickel oxide and variable magnetic fields on the change in the biological properties of black soil of the solonetzic peninsula of Crimea (Russia). Political Internet electronic scientific journal of the Kuban State Agrarian University. 104, 592, 2014.

46. HATFIELD R.G., STONER J.S., CARLSON A.E., et al. Source as a controlling factor on the quality and interpretation of sediment magnetic records from the northern North Atlantic. Earth and Planetary Science Letters, 368, 69, 2013.

47. DENG K., DING J.L., YANG A.X., WANG J.J. Modeling of the spatial distribution of soil profile salinity based on the electromagnetic induction technique. Shengtai Xuebao. Acta Ecologica Sinica, 36 (20), 6387, 2016.

48. GLUVSHTEIN A.YA. Low-frequency fluctuations in conductivity in water and aqueous solutions of sodium and potassium chlorides. Biophysics, 41 (3), 559, 1996.

49. KANU M.O., MELUDU O.C., BASAVAIAH N., ONIKU A.S. Relationship between mineral magnetic properties and soil textural parameters. Acta Geophysica, 67 (2), 517, 2019.

50. MENSHOV O. Theory and methodology of soil magnetism in geology, ecology and soil science. $12^{\text {th }}$ International Scientific Conference on Monitoring of Geological Processes and Ecological Condition of the Environment; Kyiv; Ukraine; 13-16 November; 143684, 2018.

51. WANG Y., WEI H., LI Z. Effect of magnetic field on the physical properties of water. Physics, 8, 262, 2018. 